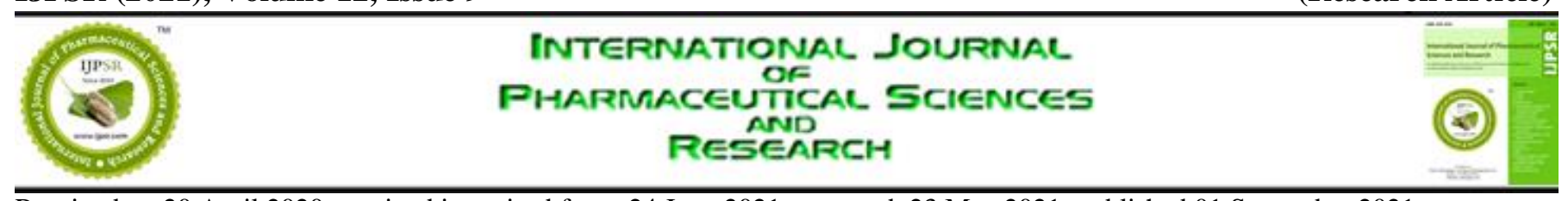

Received on 20 April 2020; received in revised form, 24 June 2021; accepted, 23 May 2021; published 01 September 2021

\title{
SYNTHESIS, CHARACTERIZATION AND BIOLOGICAL ACTIVITY OF SOME NOVEL TRIAZOLE DERIVATIVES
}

Khushboo Arora *, Sumeet Prachand, Hemant Khambete and Sanjay Jain

Faculty of Pharmacy, Medicaps University Indore - 453331, Madhya Pradesh, India.

Keywords:

Triazole, Antibacterial activity, Antifungal activity, Heterocyclic, Antimicrobial

Correspondence to Author:

Mrs. Khushboo Arora

Assistant Professor,

Faculty of Pharmacy,

Medicaps University Indore - 453331,

Madhya Pradesh, India.

E-mail: naik.khushboo@gmail.com
ABSTRACT: Triazole is a diunsaturated heterocyclic compound that contains two nitrogen groups as heteroatoms. In the present study, an attempt was made to synthesize various derivatives of substituted 1, 2, 4triazol-3-yl) benzene-1-ol and assess their antimicrobial efficiency. The synthesized compounds were subjected to physical characterization and spectral analysis by IR and NMR for structure elucidation. The compounds were then subjected to evaluation of antimicrobial activity against bacterial strains Escherichia coli (Gram -ve), Pseudomonas aeruginosa (Gram -ve), Bacillus Subtili (Gram +ve), Staphylococcus aureus (Gram +ve) method using ciprofloxacin as standard and against fungal strain Aspergillus niger method using fluconazole as standard. The results of antibacterial activity show that compounds P1 and P2 and the results of antifungal activity show that compounds P3 and P4 showed equivalent activity when compared with standard while the rest of the compounds were found to be less active than standard.
INTRODUCTION: Triazole is one of a class of organic heterocyclic compounds containing a fivemembered diunsaturated ring structure composed of three nitrogen atoms and two carbon atoms at nonadjacent positions ${ }^{1}$. Triazole nucleus containing drugs have been reported to possess diverse pharmacological activities such as fungicidal, insecticidal, bactericidal, herbicidal, antitumor, anti-inflammatory, CNS stimulant properties ${ }^{2}$. The chemistry of heterocyclic compounds continues to be an explore field in organic chemistry. The importance of triazole derivatives lies in the field that these have occupied a unique position in heterocyclic chemistry due to their antimicrobial activity ${ }^{6}$.

\begin{tabular}{|l|c|}
\hline QUICK RESPONSE CODE & DOI: \\
\hline DOI link: http://dx.doi.org/10.13040/IJPSR.0975-8232.12(9).4858-63 \\
\end{tabular}

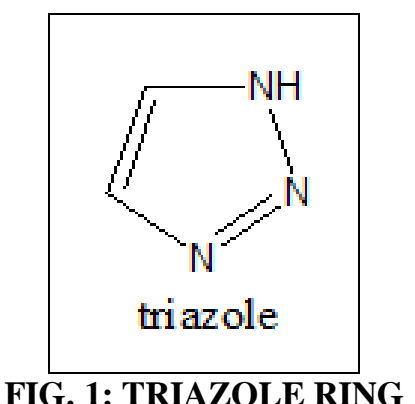

MATERIALS AND METHODS: Basing upon the developed Synthetic scheme raw materials, chemicals and apparatus of optimum quality were procured from renowned suppliers. Melting points were recording using electrically heating melting point apparatus. The homogeneity and purity of synthesized compound was ascertained by using TLC, performed on silica gel G coated plates using ethyl acetate and pet. Ether (1:1) an eluent, the developed plates were observed under an iodine chamber. SHIMADZU Model No.FTIR:8400S spectrophotometer, Bruker advance II $400 \mathrm{MHz}$ NMR spectrophotometer, LC-MSD- Tranp SL 
2010. A SHIMADZU were used for structural elucidation of compounds.
The compounds were prepared according to the established method shown in schematic diagram.

\section{Scheme of Work:}

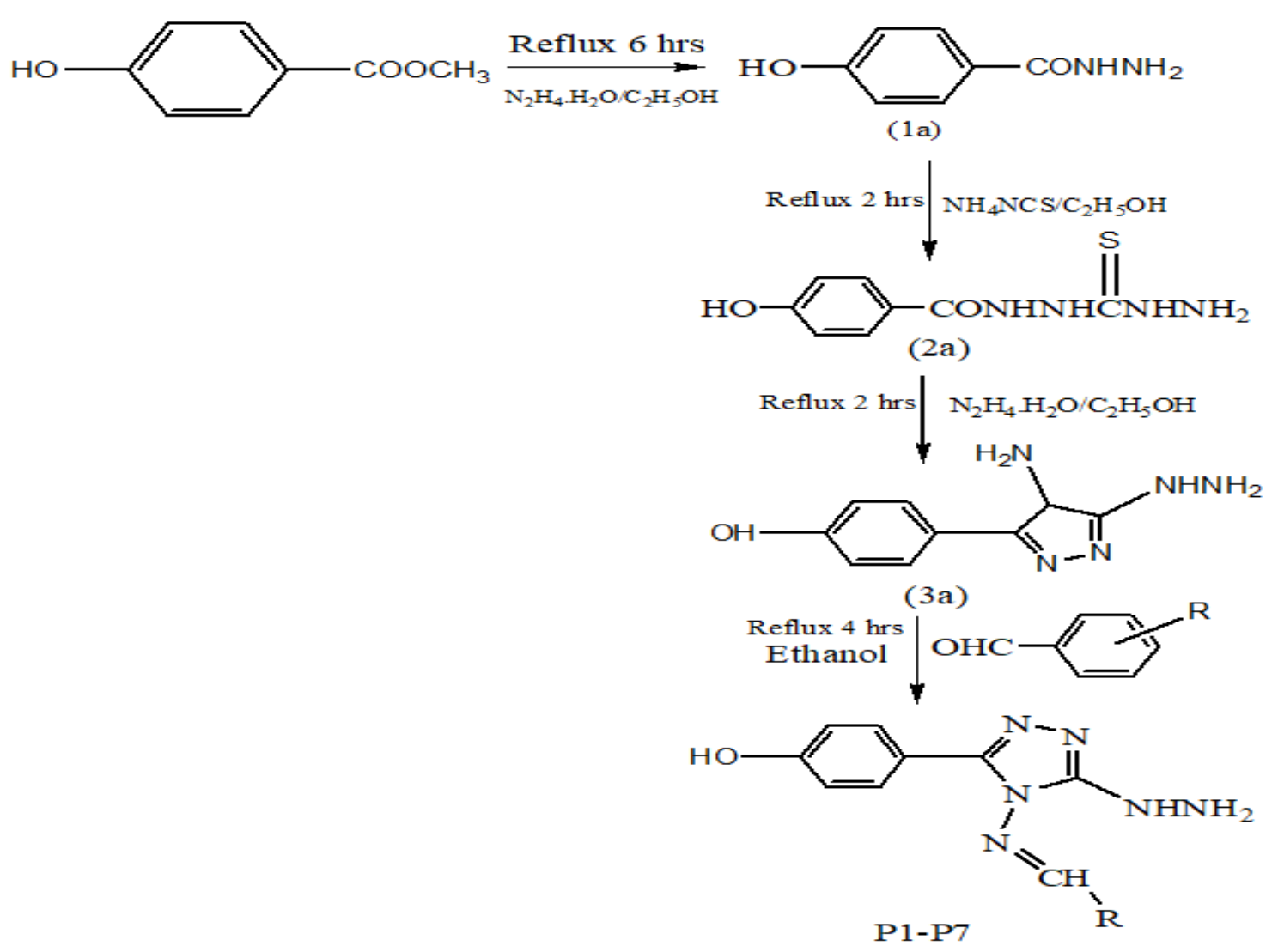

TABLE 1: LIST OF AROMATIC ALDEHYDE SUBSTITUENTS

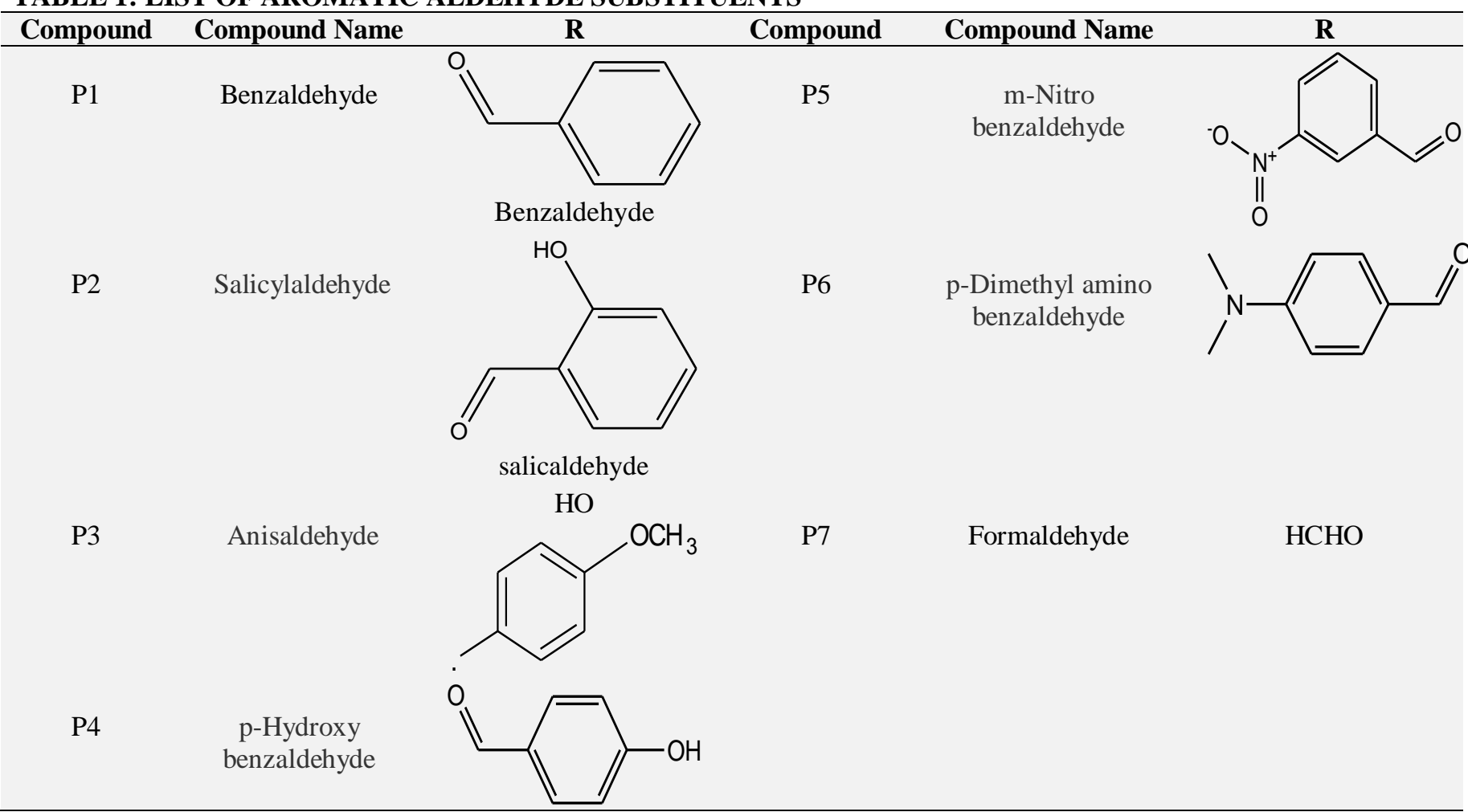




\section{General Synthetic Procedure:}

Step 1: Synthesis of 4-hydroxybenzohydrazide: Methylparaben (0.01 moles) and hydrazine hydrate (0.01 moles) were mixed gently in ethanol and refluxed for $6 \mathrm{hrs}$. The mixture is then cooled and poured into ice-cold water. Filtered off the crystals and recrystallized from ethanol. Completing the reaction was monitored on TLC using silica gel-G coated plates using ethyl acetate and petroleum ether $(1: 1 \mathrm{v} / \mathrm{v})$ as the solvent system and observed in an iodine chamber.

Step 2: Synthesis of 2-[(4-hydroxybenzohydrazide) carbonyl]-N-hydrazine substitutedcarbothioamide: A mixture of 4-hydroxybenzohydrazide (0.01 moles) and ammonium is thiocyanate $(0.001$ moles $)$ in ethanol $(25.0 \mathrm{ml})$ was refluxed on a water bath for $2 \mathrm{hrs}$. The solvent was concentrated, and the precipitated product was filtered, dried, and recrystallized from methanol.

Completing the reaction was monitored on TLC using silica gel-G coated plates using ethyl acetate and petroleum ether $(1: 1 \mathrm{v} / \mathrm{v})$ as the solvent system and observed in the iodine chamber.

Step 3: Synthesis of 4-(4-amino-5-(substituted amino)-4H-1, 2, 4-triazol-3-yl) benzene-1-ol: Compound 2-[(4-hydroxyphenyl) carbonyl]-Nhydrazine substituted carbothioamide $(0.002 \mathrm{~mol})$ and hydrazine hydrate $(0.025 \mathrm{~mol})$ was refluxed in methanol for $2 \mathrm{hrs}$, at a temperature between 50 $60^{\circ} \mathrm{C}$, reaction mixture was cooled and poured over crushed ice. Solid was filtered and recrystallized from methanol. The completion of the reaction was monitored on TLC using silica gel-G coated plates by using ethyl acetate and petroleum ether $(1: 1 \mathrm{v} / \mathrm{v})$ as the solvent system and observed in an iodine chamber.

Step 4: Synthesis of 4-(4-(substituted benzylidene amino)-5-(substituted amino)-4H-1, 2, 4triazol-3-yl) benzene-1-ol (P1-P7): To a solution of 5-(4-amino-5-(substituted amino)-4H-1, 2, 4triazol-3-yl) benzene-2-ol (0.01 Moles) in absolute ethanol $(30 \mathrm{ml})$, the appropriate aromatic aldehydes (0.012 moles) was added.

The reaction mixture was refluxed for $4 \mathrm{~h}$. After cooling, the formed solid was filtered off and recrystallized to give the title compounds respectively (P1-P7).
The completion of the reaction was monitored on TLC using silica gel-G coated plates by using ethyl acetate and petroleum ether $(1: 1 \mathrm{v} / \mathrm{v})$ as the solvent system and observed in an iodine chamber.

Characterization of Synthesized Compounds: Yield $80.52 \%$ as a solid; m.p ${ }^{\circ} \mathrm{C}$; UV (Et OH) $\lambda_{\max }$ $(\log \varepsilon)$ 272.5; IR (KBr) vmax3215 (O-H str.), 3043(=C-H str.), 2640 (C=N str.), 1269 (C-O str.), 1618 (C=C str.), 1276 (C-N str.) cm-1; ${ }^{1} \mathrm{HNMR}$ (400 MHz, DMSO): $\delta(\mathrm{ppm}): 4.0(\mathrm{~s}, 1 \mathrm{H}, \mathrm{NH}) ; 6.94-$ $7.87(\mathrm{~m}, 8 \mathrm{H}, \mathrm{Ar}-\mathrm{H}) ; 8.88(\mathrm{~s}, 1 \mathrm{H}, \mathrm{CH}) ; 2.56(\mathrm{~s}, 2 \mathrm{H}$, $\left.\mathrm{NH}_{2}\right) ; 6.91(\mathrm{~s}, 2 \mathrm{H}, \mathrm{OH})$; 13CNMR $\left(\mathrm{CDCl}_{3}, 300\right.$ $\mathrm{MHz}): \delta=154.3,124.9,162.9,122.6,130.1,102.8$, 152.6, 138.2, 151.8, 102.2, 56.1, 55.3, 56.8.

4-(4-(2-hydroxy benzylidene amino)-5(substituted amino)-4H-1, 2, 4- triazol-3-yl) benzene-1-ol: Yield $74.2 \%$ as a solid; m.p 168$170{ }^{\circ} \mathrm{C}$; UV (Et OH) $\lambda_{\max }(\log \varepsilon) 262.5$; IR (KBr) $v \max 3365$ (O-H str.), 3116(=C-H str.), 2362(C=N str.), 1016 (C-O str.), 1613(C=C str.), 1044 (C-N str.) cm- $1{ }^{1} \mathrm{HNMR}(400 \mathrm{MHz}, \mathrm{DMSO}): \delta$ (ppm): 3.88 (s, 1H, NH); 6.84-8.38 (m, 8H, Ar-H); 8.60 (s, $1 \mathrm{H}, \mathrm{CH}) ; 2.56\left(\mathrm{~s}, 2 \mathrm{H}, \mathrm{NH}_{2}\right) ; 6.82(\mathrm{~s}, 1 \mathrm{H}, \mathrm{OH})$, 3.82(s, 3H, $\left.\mathrm{CH}_{3}\right) ; 13 \mathrm{CNMR}(\mathrm{CDCl} 3,300 \mathrm{MHz})$ : $\delta=184.3,134.9,182.9,132.6,140.1,102.8,152.6$, 138.2, 141.8, 112.2, 58.1, 54.3, 56.8; Anal. Cacld for $\mathrm{C}_{16} \mathrm{H}_{15} \mathrm{~N}_{6} \mathrm{O}$ S2: C, 56.81; H, 2.80; F, 5.29; N, 3.90; O, 13.36; S, 17.84 .

4- (4- (2- Methoxy benzylidene amino)- 5(substituted amino)- 4H- 1, 2, 4- triazol-3-yl) benzene-1-ol: Yield $71.0 \%$ as a solid; m.p 180$182^{\circ} \mathrm{C}$; UV (Et OH) $\lambda_{\max }(\log \varepsilon) 235$; IR $(\mathrm{KBr})$ $v \max 3514(\mathrm{O}-\mathrm{H}$ str. $), 3216(=\mathrm{C}-\mathrm{H}$ str.), $2399(\mathrm{C}=\mathrm{N}$ str.), 1171(C-O str.), 1603(C=C str.), $1240(\mathrm{C}-\mathrm{N}$ str.) $\mathrm{cm}^{-1} ;{ }^{1} \mathrm{HNMR}$ (400 MHz, DMSO): $\delta$ (ppm): 3.49 (s, 1H, NH); 6.86-7.97 (m, 8H, Ar-H); 8.33 (s, $1 \mathrm{H}, \mathrm{CH}) ; 2.55\left(\mathrm{~s}, 2 \mathrm{H}, \mathrm{NH}_{2}\right) ; 6.79(\mathrm{~s}, 2 \mathrm{H}, \mathrm{OH})$; 13CNMR (CDCl3, $300 \mathrm{MHz}): \delta=164.3,144.9$, $172.9,135.6,148.1,142.8,182.6,148.2,149.8$, 152.2, 57.1.

4- (4- (4- Hydroxy benzylidene amino)- 5(substituted amino)-4H- 1, 2, 4- triazol- 3-yl) benzene-1-ol: Yield $72.6 \%$ as a solid; m.p 235$237^{\circ} \mathrm{C}$; UV (Et OH) $\lambda \max (\log \varepsilon) 245$; IR $(\mathrm{KBr})$ vmax 3352(O-H str.), 3165(=C-H str.), 1263 (C-O str.), 1645 (C=C str.), 1350 (C-N str.), 1508 (C$\mathrm{NO}_{2}$ str.) $\mathrm{cm}^{-1} ;{ }^{1} \mathrm{HNMR}(400 \mathrm{MHz}, \mathrm{DMSO}): \delta$ 
(ppm): 3.79 (s, 1H, NH); 6.81-8.87 (m, 8H, Ar-H); $8.54(\mathrm{~s}, 1 \mathrm{H}, \mathrm{CH}) ; 2.53\left(\mathrm{~s}, \mathrm{~S} 2 \mathrm{H}, \mathrm{NH}_{2}\right) ; 5.82(\mathrm{~s}, 1 \mathrm{H}$, $\mathrm{OH})$. ; 13CNMR $\left(\mathrm{CDCl}_{3}, 300 \mathrm{MHz}\right): \delta=174.3$, $144.9,162.9$, 125.6, 158.1, 142.8, 172.6, 138.2, 149.8, 132.2, 58.1. Anal. Cacld for $\mathrm{C}_{16} \mathrm{H}_{15} \mathrm{~N}_{6} \mathrm{O} \mathrm{S} 2$ : C, 5481; H, 1.80; F, 6.29; N, 4.90; O, 3.36; S, 7.84.

4-(4-(3-Nitro benzylidene amino)-5-(substituted amino)-4H-1, 2, 4- triazol-3-yl) benzene-1-ol: Yield $71 \%$ as a solid; m.p $199-201^{\circ} \mathrm{C}$; UV (Et OH) $\lambda_{\max }(\log \varepsilon) 245$; IR (KBr) $v_{\max } 3235$ (O-H str.), 3150(=C-H str.), 1234 (C-O str.), 1605 (C=C str.), 1369(C-N str.) $\mathrm{cm}^{-1} ;{ }^{1} \mathrm{HNMR}$ (400 MHz, DMSO): $\delta$ (ppm): 3.55 (s, 1H, NH); 6.86-8.31 (m, 8H, Ar$\mathrm{H}) ; 9.97(\mathrm{~s}, 1 \mathrm{H}, \mathrm{CH}) ; 2.95\left(\mathrm{~s}, 2 \mathrm{H}, \mathrm{NH}_{2}\right) ; 6.66(\mathrm{~s}$, $1 \mathrm{H}, \mathrm{OH}), 3.01\left(\mathrm{~s}, 6 \mathrm{H}, \mathrm{CH}_{3}\right)$; 13CNMR (CDCl3, 300 $\mathrm{MHz}): \delta=154.3,154.9,162.9,135.6,148.1,132.8$, 142.6, 128.2, 139.8, 135.2, 54.1. Anal. Cacld for $\mathrm{C}_{18} \mathrm{H}_{20} \mathrm{~N}_{7} \mathrm{O}_{2} \mathrm{~S} 2$ : C, 581; H, 3.80; F, 5.39; N, 6.90; O, 7.36; S, 4.84 .

4-(4-(4-dimethyl amino benzylidene amino)-5(substituted amino)-4H-1, 2, 4- triazol-3-yl) benzene-1-ol: Yield $73.2 \%$ as a solid; m.p 188$190^{\circ} \mathrm{C}$; UV (Et OH) $\lambda_{\max }(\log \varepsilon) 235$; IR (KBr) $v_{\max }$ 3235 (O-H str.), 3150(=C-H str.), 1234 (C-O str.), 1605 (C=C str.), 1369(C-N str.) cm ${ }^{-1} ;{ }^{1} \mathrm{HNMR}$ (400 $\mathrm{MHz}, \mathrm{DMSO}): \delta(\mathrm{ppm}): 3.55(\mathrm{~s}, 1 \mathrm{H}, \mathrm{NH}) ; 6.86-$ 8.31 (m, 8H, Ar-H); 9.97 (s,1H, CH); 2.95(s, 2H, $\left.\mathrm{NH}_{2}\right) ; 6.66(\mathrm{~s}, 1 \mathrm{H}, \mathrm{OH}), 3.01\left(\mathrm{~s}, 6 \mathrm{H}, \mathrm{CH}_{3}\right)$; 13CNMR $\left(\mathrm{CDCl}_{3}, 300 \mathrm{MHz}\right): \delta=154.3,154.9$, $162.9,135.6,148.1,132.8,142.6,128.2,139.8$, 135.2, 54.1. Anal. Cacld for $\mathrm{C}_{18} \mathrm{H}_{20} \mathrm{~N}_{7} \mathrm{O}_{2} \mathrm{~S} 2$ : C, 581; H, 3.80; F, 5.39; N, 6.90; O, 7.36; S, 4.84.

Biological Evaluation: Bacterial strain $A$. Escherichia coli (Gram -ve) B. Pseudomonas aeruginosa (Gram -ve) C. Bacillus Subtili (Gram +ve) D. Staphylococcus aureus (Gram +ve) in present study the cup-plate method was used to evaluate the antimicrobial activity in vitro of the synthesized compounds. This method was used for determining the selective effectiveness of the antibacterial activity.

The standard antibiotic selected for the study of the antibacterial activity was ciprofloxacin Baselayer was obtained by pouring about $10-15 \mathrm{ml}$ of the base layer medium into each sterilized Petri dish and allowed to attain room temperature. The overnight grown sub-culture was taken into definite volume of inoculated, then with the help of cotton swab the organisms were streaked the entire agar surface horizontally, vertically, and around the outer edge of the plate to ensure a heavy growth over the entire surface. Allow all culture plates to dry for about 5 minutes. Scooping out nutrient agar with sterilized cork borer made the cups. The solution of the test compounds $(0.1 \mathrm{ml})$ was added into the cups by using micropipettes, and these plates were subsequently incubated all the plate cultures in an inverted position for 24 hats $37^{\circ} \mathrm{C}$ and observed for antimicrobial activity. Ciprofloxacin $(10 \mu \mathrm{g} / \mathrm{ml})$ was used as a standard drug, and the solvent control (DMSO) was kept separately. After $24 \mathrm{hrs,} \mathrm{the}$ diameters of zone of inhibition were measured for the plates in which the zones of inhibition and minimum inhibitory concentration (MICs) were measured in $\mathrm{mm}$ for each organism. Zone of inhibition was determined for all the ten compounds the results in the form of percent inhibition were summarized.

Fungal Strain was used Aspergillus niger: In the present study, the cup-plate method was used to evaluate the antimicrobial activity in vitro of the synthesized compounds.

This method was used for determining the selective effects of the anti-fungal activity. The standard antibiotic selected for the study of the antibacterial activity was fluconazole. Sabouraud's dextrose agar (SDA) was used for the growth of the fungal culture.

The same procedure as that for assaying the antibacterial activity was adopted, and fungal cultures were kept for $48 \mathrm{hr}$ to determine the diameter of the zone of inhibition. Fluconazole (1 $\mathrm{mg} / \mathrm{ml}$ ) was used as standard.

The Microbiological testing has been performed for bacterial and fungal species and the following values were determined.

$$
\begin{aligned}
& >\text { MIC value. } \\
& >\text { Zone of Inhibition. }
\end{aligned}
$$

Antimicrobial Activity: Antimicrobial Activity of Compounds P1-P7 using Cup-Plate Method: Antibacterial activity Growth Medium-Nutrient Agar. 
TABLE 2: MICS (MINIMUM INHIBITORY CONCENTRATIONS) ( $\mu \mathrm{g} / \mathrm{ml})$ ZONE OF INHIBITION OF THE SYNTHETIC COMPOUNDS

\begin{tabular}{|c|c|c|c|c|}
\hline \multicolumn{5}{|c|}{ Zone diameter in mm } \\
\hline \multirow[b]{2}{*}{ Compounds } & \multicolumn{2}{|c|}{ Gram-positive bacteria } & \multicolumn{2}{|c|}{ Gram-negative bacteria } \\
\hline & Staphylococcus aureus & Bacillus subtilis & Escherichia coli & Pseudomonas aeruginosa \\
\hline P1 & $9.31(6.25)$ & $9.11(6.25)$ & $9.45(6.25)$ & $9.69(6.25)$ \\
\hline P2 & $9.23(6.25)$ & $9.32(6.25)$ & $9.61(6.25)$ & $9.51(6.25)$ \\
\hline P3 & $9.24(6.25)$ & $8.87(6.25)$ & $9.17(6.25)$ & $9.53(6.25)$ \\
\hline P4 & $9.13(6.25)$ & $8.99(6.25)$ & $9.23(6.25)$ & $9.33(6.25)$ \\
\hline P5 & $9.21(6.25)$ & $9.12(6.25)$ & $9.17(6.25)$ & $9.59(6.25)$ \\
\hline P6 & - & - & - & - \\
\hline P7 & & & & \\
\hline Ciprofloxacin as standard & $25.21(6.25)$ & $23.68(6.25)$ & $22.41(6.25)$ & $18.85(6.25)$ \\
\hline
\end{tabular}

Antifungal Activity:

Growth Medium: Subouraud dextrose agar.

TABLE 3: IN-VITRO ANTIFUNGAL ACTIVITY OF SYNTHESIZED COMPOUNDS

\begin{tabular}{ccc}
\hline S. no. & Sample ID & Aspergillus niger \\
\hline 1 & P1 & $9.07(12.5)$ \\
2 & P2 & $9.24(12.5)$ \\
3 & P3 & $9.08(6.25)$ \\
4 & P4 & $9.22(6.25)$ \\
5 & P5 & $9.35(12.5)$ \\
6 & P6 & - \\
7 & P7 & - \\
Standard & Fluconazole & $9.02(6.25)$ \\
\hline
\end{tabular}

CONCLUSION: Antibacterial activity of synthesized compounds revealed that compounds $\mathrm{P} 1$ and $\mathrm{P} 2$ possess potent antibacterial activities over rest of the compounds. P1 and P2 are more potent against Pseudomonas aeruginosa and E. coli with respect to ciprofloxacin with MIC value 6.25 $\mu \mathrm{g} / \mathrm{ml} \& 12.5 \mu \mathrm{g} / \mathrm{ml}$, respectively. Compound P3, P4 and P5 exhibited moderate activity. Whereas comparable MIC against Bacillus subtilis and Staphylococcus aureus. And antifungal activity of the synthesized compounds revealed that compounds $\mathrm{P} 3$ and $\mathrm{P} 4$ possess potent antifungal activities over rest of the compounds. P3 and P4 are more potent against Aspergillus niger with respect to fluconazole with MIC values $6.25 \mu \mathrm{g} / \mathrm{ml}$ and $12.5 \mu \mathrm{g} / \mathrm{ml}$, respectively. And rest of the compound has moderate antifungal activity. The preliminary SAR revealed that different aromatic aldehyde favors antibacterial and anti-fungal activity of 1,2, 4 triazoles. Anti-fungal activity data indicated that they have more potency over reference.

ACKNOWLEDGEMENT: The authors are highly thankful to the Dean Faculty of Pharmacy, Medi-Caps University, and providing the necessary facilities to carry out this research.
CONFLICTS OF INTEREST: Nil

\section{REFERENCES:}

1. Hoyer C, Schwerk P, Suntrup L, Beerhues J, Nössler M, Albold U, Dernedde J, Tedin K and Sarka B: Synthesis, characterization, and evaluation of antibacterial activity of ferrocenyl-1,2,3-triazoles, triazolium salts, and triazolylidene complexes of Gold(I) and Silver(I). European Journal of Inorganic Chemistry 2021; 14: 137382.

2. Mukesh Kumari, Sumit Tahlan, Balasubramanian Narasimhan, Kalavathy Ramasamy, Siong Meng Lim, Syed Adnan Ali Shah, Vasudevan Mani and Saloni Kakkar: Synthesis and biological evaluation of heterocyclic 1, 2, 4-triazole scaffolds as promising pharmacological agents. BMC Chemistry volume 15(5): 2021. doi: 10.1186/s13065-020-00717-y.

3. Eugenia Stingaci, Marina Zveaghinteva, Serghei Pogrebnoi and Lucian Lupascu: New vinyl-1, 2, 4-triazole derivatives as antimicrobial agents: Synthesis, biological evaluation and molecular docking studies. Bioorganic \& Medicinal Chemistry Letters Volume Issue 30(117): 2020.

4. Aly AA, Hassan AA, Makhlouf MM and Bräse S: Chemistry and biological activities of 1, 2, 4triazolethiones-antiviral and anti-infective drugs. Molecules 2020; 25: 3036.

5. El-Reedy AAM and Soliman NK: Synthesis, biological activity and molecular modeling study of novel 1,2,4triazolo[4,3-b][1,2,4,5] tetrazines and 1,2,4-triazolo[4,3-b] $[1,2,4]$ triazines, Scientific Reports 2020; 10: 6137.

6. Głowacka IE, Grzonkowski P, Lisiecki P, Malinowski L and Piotrowska DG: Synthesis and antimicrobial activity of novel 1,2,3-triazole-conjugates of quinazolin-4-ones, doi.org/10.1002/ardp.201800302

7. Strzelecki M and Swiatek P: 1,2,4-triazoles as important antibacterial agents. Pharmaceuticals 2021; 14: 224.

8. Valdés AKE and Cuevas-Yanez E: Design and Synthesis of antifungal compounds from 1,2,3-triazoles through the click chemistry approach. Organic \& Medicinal Chem IJ 2019; 8(2): 555734.

9. Ram VJ, Sethi A, Nath M and Pratap R: The chemistry of heterocycles nomenclature and chemistry of three-to-five membered heterocycles, Elsevier 2019; 149-78.

10. Yang L and Bao XP: Synthesis of novel 1,2,4-triazole derivatives containing the quinazolinylpiperidinyl moiety and $\mathrm{N}$-(substituted phenyl)acetamide group as efficient bactericides against the phytopathogenic bacterium Xanthomonas oryzae pv. Oryzae. The Royal Society of Chemistry 2017; 7: 34005. 
11. Paproc R, Wieseka M and Eljaszewicz A: Synthesis and anti-inflammatory activity of new 1,2,4-triazole derivatives. Bioorganic \& Medicinal Chemistry Letters Elsevier 2015; 2(3): 2664-667.

12. Güniz Ş, Küçükgüzel and Çıkla-Süzgün P: Recent advances bioactive 1, 2, 4-triazole-3-thiones. European Journal of Medicinal Chemistry 2015; 2(6): 830-70.

13. Taj T, Kamble RR, Dorababu A and Meti GY: Synthesis of novel 1,2, 4-triazole derivatives as antimicrobial agents via the japp-klingemann reaction: investigation of antimicrobial activities. Hindawi Publishing Corporation Journal of Chemistry 2013; ID 909706.

14. Mathew V, Keshavaya J and Pandaya VP: Heterocyclic system containing bridgehead nitrogen atom: synthesis and pharmacological activities of some substituted 1, 2, 4triazolo [3, 4-b]-1, 3, 4-thiadiazoles. European Journal of Medicinal Chemistry 2006; 41: 1048-058.

15. Collins LA and Franzblau SG: Micro plate alamar blue assay versus BACTEC 460 system for high throughput screening of compounds against Mycobactrium avium, Antimicrob agents Chemother 1997; 14: 1004-009.

16. Foye WO, Willlims DA and Lemke TL: Principles of Medicinal Chemistry 5th ed., Wilkins Production, New York 2002; 17-21.

17. Wilson and Gisvold's Text book of organic medicinal and pharmaceutical chemistry, Eleventh edition, p p.1-3.

18. Thomas L Lemke, David A Williams, Victoria F Roche and S Williams Zito: Foye's principle of medicinal chemistry, $6^{\text {th }}$ Edition 1-2.

19. Singh $\mathrm{H}$ and Kapoor VK: Medicinal and pharmaceutical chemistry edition $2005 ; 1-2$.

20. Kar A: Text book of Medicinal chemistry, revised 3rd edition pp. 1-3.

21. Wolf ME: Burger's Medicinal Chemistry and Drug Discovery," Volume 4, $6^{\text {th }}$ ed, Wiley-interscience, New York 1995; 1-5.

22. Ilango $K$ and Valentina $P$ : Text book of Medicinal Chemistry," Volume 2, $1^{\text {st }}$ Ed, 2007; 381-95.

23. James R, Fromm: Introduction to Aromatic Hydrocar 1997

24. Mohammad A and Rabiul MI: Synthesis of some bis' triazole derivatives as probes for cytotoxicity study. Bangladesh Journal of Pharmacology 2006; 1: 21-26.

25. Final Report on the Amended Safety Assessment of Propyl Gallate". Inter J of Toxicology 2007; 26 (3): 89-118.

26. Indian Pharmacopoeia, Ministry of health and family welfare Govt. of India, New Delhi 2007; 3: 1611.

27. Block JH, Beale JM, Wilson and Gisvolds: Textbook of organic medicinal and pharmaceutical chemistry $9^{\text {th }}$ ed.,
Lippincott Williams and Wilkins publication, New York 1991; 40-55.

28. Fusco S, Centore R, Riccio P and Quatela A: NLO-active polymers containing triazolo-thiadiazole segments Polymer 2008; 49: 186-91.

29. Thorsten J, Tausch L, Hoernig M, Coste O, Schmidt R, Angioni C, Metzner J, Groesch S, Pergola C, Stienhilber $\mathrm{D}$, Werz $\mathrm{O}$ and Geisslinger G: Celecoxib inhibits 5lipoxigenaseBiochem. Pharmacol 2008; 76: 862-72.

30. Lokhande SB and Rangnekar DW: Synthesis of 9-aryl and 9-heteroaryl-4, 5, 6, 9-tetrahydrobenzo-triazoloisoquinoline-4, 6-diones and napthalamides," Indian J Chem 1986; 25: 496-99.

31. Mohan J, Anjaneyelu GSR, Prithima V and Yamani KVS: Synthesis and antimicrobial activity of heterocyclic system bridgehead nitrogen atom containing S-triazolothiadiazines. Indian J Chem 1990; 29: 88-90.

32. Bansal OP, Shrinivas JS and Reddy CV: Synthesis and antimicrobial activity of some new 3, 4-diary-5aryloxymethyl-1, 2, 4-triazoles. Indian J Chem 1992; 31: 289-92.

33. Kamotra P, Gupta AK and Gupta R: Microwave assisted synthesis and biological activity of 3-alkyl/aryl-6(1chloro-3, 4-dihydro-napth-2-yl)-5, 6-dihydro-S-triazolothiadiazoles. Indian J Chem 2007; 46: 980-84.

34. Udapi RH, Rajeeva B, Sethi R, Shivansulu N, Pasha TY, Kumar BS and Bhatt AR: Synthesis and bioactivity of some 3,5-di substituted-6-thiono-S-triazolo-thiadiazoles. Indian J Hetero Chem 2004; 13: 229-32.

35. Amir M, Kumar $\mathrm{H}$ and Javed SA: Condensed bridgehead nitrogen heterocyclic system: Synthesis and pharmacological activities of 1, 2, 4-triazolo (3, 4-b) 1, 3, 4-thiadiazole derivatives of ibuprofen and biphenyl -4yloxy acetic acidEur J Med Chem 2007; 6(42): 431-36.

36. Abushahma and Tripathi DS: Synthesis of some new triaryl -S-triazolo-thiadiazole-S-triazine-5-thiones," Indian JHetero Chem 2006; 16: 121.

37. Peng-Fei X, Zi-Hui Z and Rong-Liang Z: Synthesis of triazoles, oxadiazoles and condensed heterocyclic compounds containing cinchopheny and studies on biological activity of representative compounds, some of the representative compounds were screened for antibacterial activity. Journal of Chinese Chemical Society 2004; 51: 315-19.

38. Kumar NA, Ganguli S and Chakraborty R: Antibacterial activity of some 3-(Arylideneamino)-2-phenylquinazoline$4(3 \mathrm{H})$-ones: Synthesis and preliminary QSAR studies 2007; 12: 2413-26.

How to cite this article:

Arora K, Prachand S, Khambete H and Jain S: Synthesis, characterization and biological activity of some novel triazole derivatives. Int J Pharm Sci \& Res 2021; 12(9): 4858-63. doi: 10.13040/IJPSR.0975-8232.12(9).4858-63.

All @ 2021 are reserved by the International Journal of Pharmaceutical Sciences and Research. This Journal licensed under a Creative Commons Attribution-NonCommercial-ShareAlike 3.0 Unported License.

This article can be downloaded to Android OS based mobile. Scan QR Code using Code/Bar Scanner from your mobile. (Scanners are available on Google Playstore) 